\title{
A rapid chemical method for lysing Arabidopsis cells for protein analysis
}

\author{
Daisuke Tsugama', Shenkui Liu² and Tetsuo Takano ${ }^{1 *}$
}

\begin{abstract}
Background: Protein extraction is a frequent procedure in biological research. For preparation of plant cell extracts, plant materials usually have to be ground and homogenized to physically break the robust cell wall, but this step is laborious and time-consuming when a large number of samples are handled at once.

Results: We developed a chemical method for lysing Arabidopsis cells without grinding. In this method, plants are boiled for just 10 minutes in a solution containing a $\mathrm{Ca}^{2+}$ chelator and detergent. Cell extracts prepared by this method were suitable for SDS-PAGE and immunoblot analysis. This method was also applicable to genomic DNA extraction for PCR analysis. Our method was applied to many other plant species, and worked well for some of them.
\end{abstract}

Conclusions: Our method is rapid and economical, and allows many samples to be prepared simultaneously for protein analysis. Our method is useful not only for Arabidopsis research but also research on certain other species.

Keywords: Cell wall, pectin, $\mathrm{Ca}^{2+}$, Chelate, detergent, Arabidopsis

\section{Background}

Protein extraction is a frequent procedure in biological research. For preparation of plant cell extracts, it is usually required to grind and homogenize plant materials to physically break the robust cell wall. Sample grinding is laborious and time-consuming, especially when a large number of samples are handled at once. In the case of yeast cells, which also have a cell wall, proteins can be efficiently extracted after cells are treated with alkaline $(\mathrm{NaOH})$ and boiled in SDS-containing solution [1-3]. Although the components and structure of the yeast cell walls [4, for a review] are different from those of the plant cell wall [5, for a review], the simplicity of the yeast method tempted us to seek out a chemical cell-lysis method suitable for plant protein extraction.

Here we describe a rapid and simple way of preparing cell extracts from Arabidopsis. We found that in the presence of certain amounts of a $\mathrm{Ca}^{2+}$ chelator and detergent, Arabidopsis cells are quickly lysed just by boiling, without grinding. The method is rapid and economical,

\footnotetext{
* Correspondence: takano@anesc.u-tokyo.ac.jp

${ }^{1}$ Asian Natural Environmental Science Center (ANESC), The University of

Tokyo, 1-1-1 Midori-cho, Nishitokyo-shi, Tokyo, 188-0002, Japan

Full list of author information is available at the end of the article
}

and the cell extracts prepared by the method are suitable for SDS-PAGE and immunoblot analysis.

\section{Results and Discussion}

Effects of $\mathrm{Ca}^{2+}$-chelating agents on Arabidopsis cell lysis In an effort to develop a rapid method of sample preparation, we first simply applied the yeast "alkaline lysis" procedure [3] to Arabidopsis seedlings. Plants were incubated at $100^{\circ} \mathrm{C}$ for 10 minutes in the solution containing SDS, $\mathrm{NaOH}$, EDTA and $\beta$-ME ( $\beta$-mercaptoethanol). After the treatment, the solution turned green due to chlorophyll leakage from the cells. SDS-PAGE followed by CBB (Coomassie brilliant blue) protein staining confirmed that cytoplasmic proteins were also present in the supernatant, suggesting that this method works well in protein extraction from Arabidopsis. Because having the proper concentrations of SDS and $\mathrm{NaOH}$ in the solution was critical in the yeast method [1-3], we examined the effects of different concentrations of SDS and $\mathrm{NaOH}$ on protein extraction from Arabidopsis. SDS was indispensable for efficient protein extraction, but unexpectedly, the $\mathrm{NaOH}$ concentration had little effect on the efficiency. When a higher $(0.4 \mathrm{M})$ concentration of $\mathrm{NaOH}$ was used, less amounts of protein were detected (Figure 1). This was probably due to protein degradation but not to insufficient protein
C Biomed Central

(c) 2011 Tsugama et al; licensee BioMed Central Ltd. This is an Open Access article distributed under the terms of the Creative Commons Attribution License (http://creativecommons.org/licenses/by/2.0), which permits unrestricted use, distribution, and reproduction in any medium, provided the original work is properly cited. 


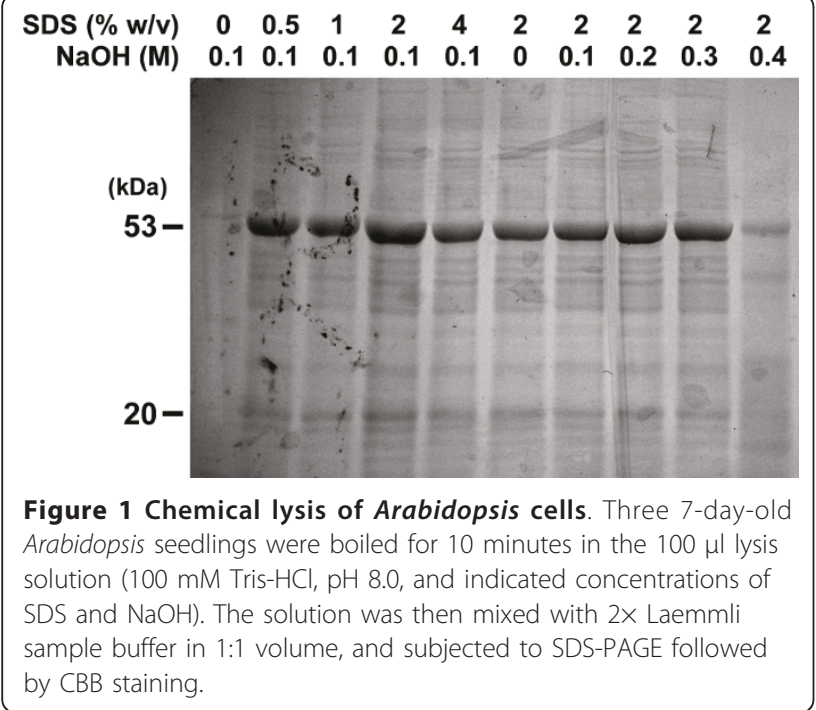

extraction, because the plant cells lost their green color and appeared to be lysed even when the $\mathrm{NaOH}$ concentration was $0.4 \mathrm{M}$ (data not shown). The $\mathrm{NaOH}$-free solution (containing SDS, EDTA and $\beta$-ME) worked well, while in preliminary experiments, $2 \times$ Laemmli sample buffer (containing SDS, and $\beta$-ME but no EDTA) [6] failed to extract proteins from unground plants. This suggested that EDTA was necessary for efficient protein extraction, and thus we examined the effects of EDTA on cell wall loosening. We heated plants in the solution containing SDS and EDTA, and saw greening of the solution by leakage of chlorophyll, the molecular weight of which is smaller than those of usual proteins, as a sign of cell wall loosening. Chlorophyll leakage increased with increasing incubation period, increasing temperature and increasing EDTA concentration. $\mathrm{A} \mathrm{Ca}^{2+}$-specific chelator, EGTA, was as effective as EDTA in extracting chlorophyll (Figure 2), suggesting that EDTA/EGTA-Ca chelate formation is involved in the cell lysis process. EDTA chelates $\mathrm{Mg}^{2+}$ or $\mathrm{Ca}^{2+}$ in a molar ratio of 1:1. In the presence of $\mathrm{MgCl}_{2}$, chlorophyll leakage was retarded but occurred to some extent, whereas excess $\mathrm{CaCl}_{2}$ strongly suppressed chlorophyll leakage. $\mathrm{NaCl}$ did not affect the efficiency of chlorophyll leakage (Figure 3). These results provide further evidence that chelating $\mathrm{Ca}^{2+}$ in the cell wall is important for efficient cell lysis. Unrestricted diffusion of molecules through the cell wall is limited by the pore size of the cell wall, and the pore size of the primary cell wall is defined by pectins [ 5 , for a review]. $\mathrm{Ca}^{2+}$ is a component of pectins, and stabilizes their structure [5, for a review]. Thus our results can be attributed to pectin solubilization by EDTA/EGTA. Cells were not lysed well when SDS treatment was followed by EDTA treatment and vice versa (data not shown), which suggests that cell lysis requires simultaneous cell wall loosening by EDTA/EGTA and membrane solubilization by SDS.

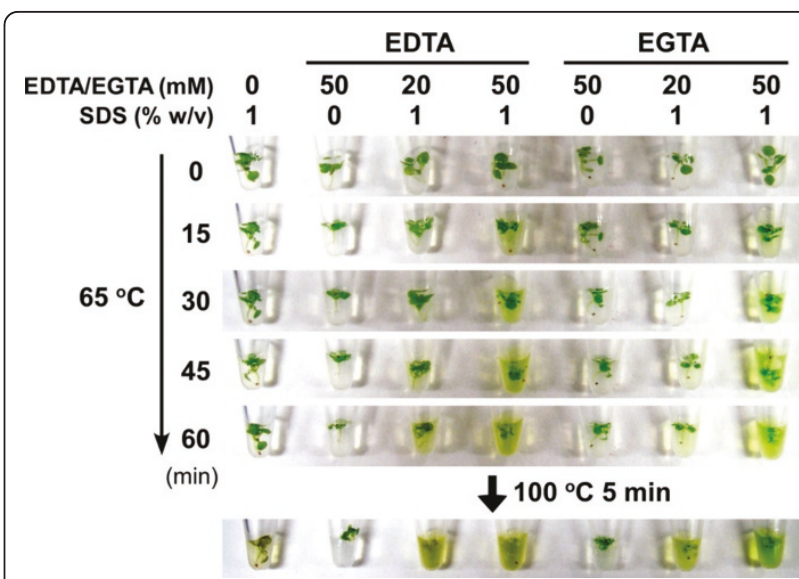

Figure 2 EDTA/EGTA-dependent Arabidopsis cell lysis. A 7-dayold Arabidopsis seedling was placed in the lysis solution (100 mM Tris- $\mathrm{HCl}, \mathrm{pH} 8.0$, and the indicated concentrations of SDS and EDTA/ EGTA), incubated at $65^{\circ} \mathrm{C}$ for 60 minutes, and then at $100^{\circ} \mathrm{C}$ for 5 minutes. Photographs were taken at the indicated time points.

We also examined effects of $\mathrm{pH}$ on cell wall loosening using Tris- $\mathrm{HCl}$ buffers with $\mathrm{pH}$ values from 6.8 to 9.6. We found that chlorophyll could be efficiently extracted without EDTA when $\mathrm{pH}$ was 8.8 or 9.6 (Figure 4). This finding is consistent with the previous studies reporting that DNA can be extracted after plants are treated by $\mathrm{NaOH}[7,8]$ or Tris- $\mathrm{HCl}, \mathrm{pH} 9.5$ [9]. When $\mathrm{pH}$ was below 8.8, chlorophyll extraction was incomplete without EDTA (Figure 4). Because an EDTA/EGTA-Ca chelate is more stable when $\mathrm{pH}$ of the solution is higher [10], we compared the efficiencies of chlorophyll extraction at $\mathrm{pH} 6.8,7.5$ and 8.0 in the presence of EDTA. The efficiency depended on the EDTA concentration rather than on $\mathrm{pH}$ or the stability of the EDTA-Ca chelate (data not shown).

The effects of EDTA and EGTA and five other $\mathrm{Ca}^{2+}$ chelators on Arabidopsis cell lysis were compared. All of the chelators were effective at a concentration of 50 $\mathrm{mM}$, while some had little or no effect at $20 \mathrm{mM}$ (Table 1 ). The effectiveness did not appear to be correlated with the chelate stability. We examined four other detergents besides SDS: an anionic detergent, SDSa (sodium N-dodecanoylsarcosinate), a zwitterionic detergent, CHAPS (3-[(3-cholamidopropyl)dimethylammonio] propane- sulfonate), and two nonionic detergents, Tween 20 and Brij 35. All except Tween-20 caused the cell lysis in combination with EDTA (data not shown). Thus, Arabidopsis cells can be rapidly lysed if they are boiled in the presence of an appropriate $\mathrm{Ca}^{2+}$ chelator and detergent.

\section{Rapid preparation of cell extracts}

Although Arabidopsis cell walls can be loosened with either a $\mathrm{Ca}^{2+}$ chelator or high $\mathrm{pH}$, highly alkaline 


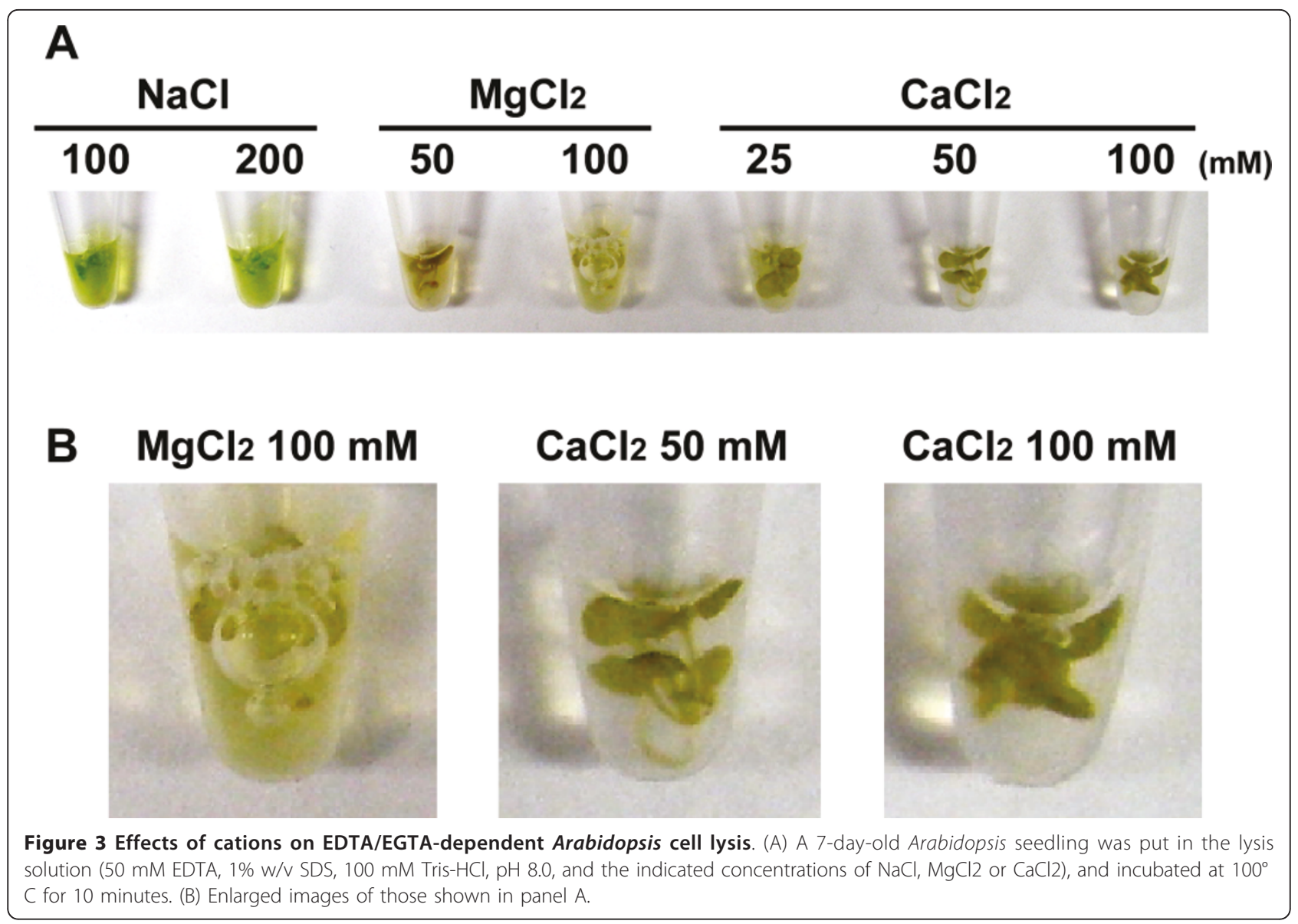

conditions can degrade proteins (Figure 1). Moreover, we observed protein degradation when plants were boiled in a solution of $\mathrm{pH} 9.6$ after $\mathrm{H}_{2} \mathrm{O}_{2}$ treatment, but not when pH 6.8 (data not shown). Therefore we adopted an EDTA-dependent cell lysis method. The sample preparation procedure is illustrated in Figure 5. In this system, samples can be loaded after just $10 \mathrm{~min}$ utes of boiling in the lysis buffer, allowing many samples to be prepared simultaneously. Plant materials up to 0.5 $\mathrm{g} / \mathrm{ml}$ could be almost completely lysed in our lysis solution (Figure 6A). Using our method or usual grinding

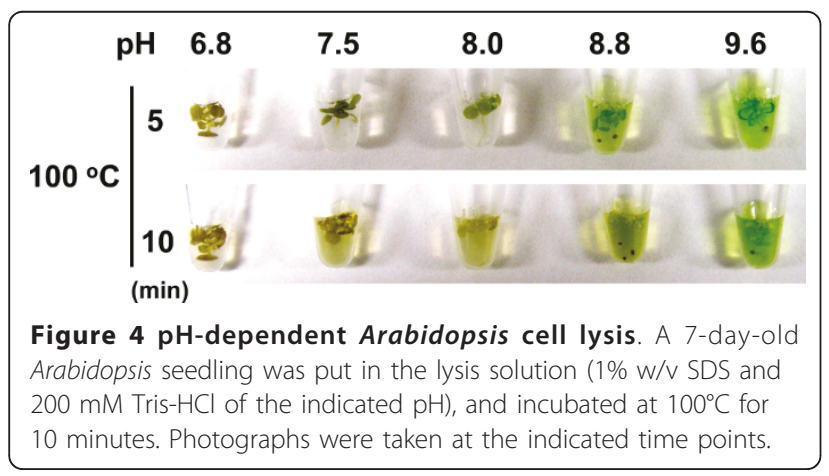

methods, we extracted proteins from the same amount $(50 \mathrm{mg}$ ) of plant tissues and compared the protein banding patterns. The protein banding pattern obtained through our method was similar to those obtained through the usual grinding methods (Figure 6B), suggesting that our method is as efficient as the usual grinding methods in extracting proteins. We performed

Table 1 Chelators used in this study

\begin{tabular}{|c|c|c|c|}
\hline \multirow[b]{2}{*}{ Chelator } & \multirow[b]{2}{*}{$\log \mathrm{K}_{\mathrm{CaL}}{ }^{* 1}$} & \multicolumn{2}{|c|}{ Cell lysis*2 } \\
\hline & & $20 \mathrm{mM}$ & $50 \mathrm{mM}$ \\
\hline EDTA & 10.96 & + & + \\
\hline EGTA & 11 & + & + \\
\hline NTA & 6.41 & - & + \\
\hline TTHA & 10.06 & - & + \\
\hline DTPA & 10.74 & - & + \\
\hline CyDTA & 12.5 & \pm & + \\
\hline BAPTA & 6.97 & + & + \\
\hline
\end{tabular}

${ }^{* 1}$ Chelate-stability constants, which are available in the Dojindo website http://www.dojindo.co.jp/.

*2 A 7-day-old Arabidopsis seedling was boiled for $10 \mathrm{~min}$ in the 50 - I lysis solution (100 mM Tris- $\mathrm{HCl}, \mathrm{pH} 8.0,1 \% \mathrm{w} / \mathrm{v}$ SDS and 20 or $50 \mathrm{mM}$ chelator listed). Samples were regarded as lysed $(+)$ or not $(-)$, based on the development of green color of the chlorophyll in the solution. 


\section{For SDS-PAGE}

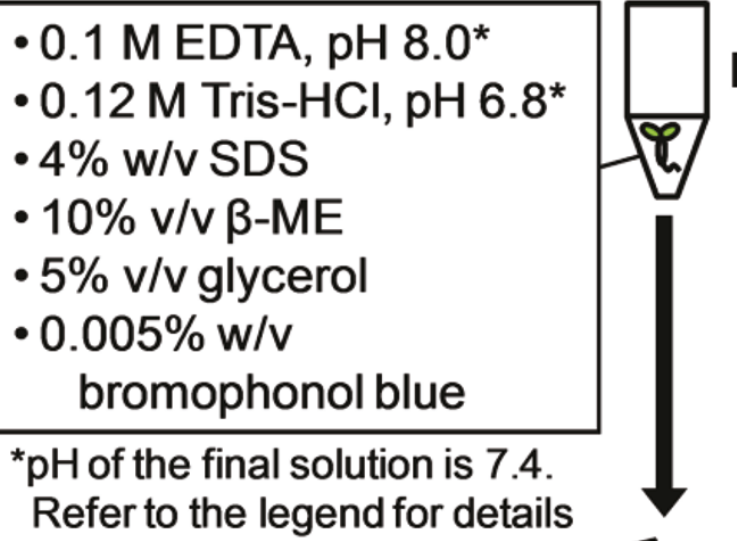

For genomic PCR

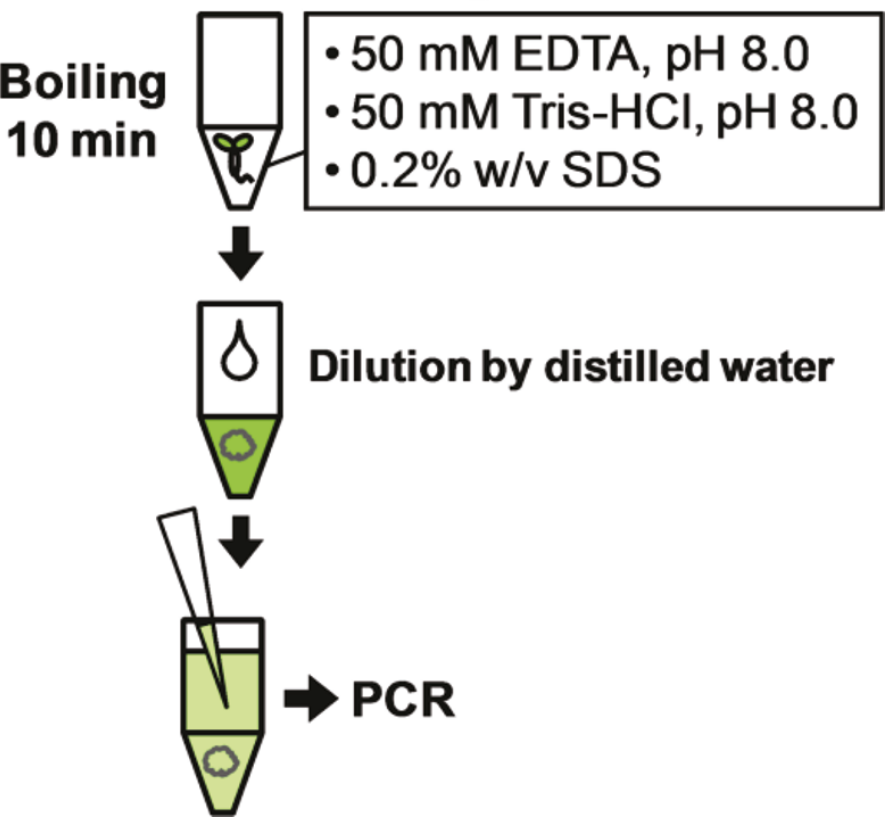

Figure 5 Diagram of rapid sample preparation for SDS-PAGE and genomic PCR analysis from Arabidopsis. The lysis solution for SDSPAGE was prepared by mixing stock solutions of its components (0.5 M EDTA, pH 8.0, 1 M Tris-HCl, pH 6.8, 10\% w/v SDS, 100\% $\beta-M E, 100 \%$ glycerol and bromophenol blue powder). The $\mathrm{pH}$ value of this solution was around 7.4. The lysis solution for genomic PCR was prepared in the same way. Arabidopsis cells can be rapidly lysed by boiling plants in the indicated solutions for 5-10 minutes (until the solution become cloudy by cell extracts). In the case of SDS-PAGE, the solution can be directly loaded onto the gel after boiling. In the case of genomic PCR, the solution is diluted after boiling ( $500 \mu \mathrm{l}$ distilled water for $50 \mu \mathrm{l}$ lysis solution) and usable as a PCR template.

immunoblot analyses as practical applications of our method. Using samples prepared by our system, we successfully detected GFP in transgenic plants and MAPK (mitogen-activated protein kinase) activation induced by the flg22 [11] or $\mathrm{H}_{2} \mathrm{O}_{2}$ treatment [12] (Figure 6B, C). In either case, degradation products were not detected (data not shown). These results confirm that our method is compatible for analysis of transgene products and physiological responses.

We also applied our method to genomic PCR analysis. PCR template was prepared by the procedure shown in Figure 5 from wild-type plants and agb1-2 mutant plants, which have a T-DNA insertion in $A G B 1$ [13]. A DNA fragment of $A G B 1$ could be amplified from the wild-type template but not from the agb1-2 template when the $A G B 1$-specific primer pair was used. On the other hand, a DNA fragment was amplified only from the agb1-2 template when a T-DNA-specific primer was used (Figure 7). Our sample preparation method is simple and quick, but without further purification of DNA, a contaminant-tolerant PCR enzyme must be used. We tried several kinds of PCR enzymes, and KOD FX gave the best results (data not shown). An excess amount of EDTA or SDS interferes with PCR. There might be a less inhibitory combination of $\mathrm{Ca}^{2+}$ chelator and detergent, though changing detergents from anionic SDS to nonionic Brij 35 did not improve the PCR efficiency in our experiment (data not shown).

Applicability of the method to different tissues and plants

Our method does not work on all plant tissues or species. Proteins could be extracted from most Arabidopsis tissues, but not from seeds, which are covered with robust seed coats (Figure 8A). The extraction method worked well for leaves of fig (Ficus carica) and downy cherry (Prunus tomentosa) (Figure 8B), but not for leaves of mulberry (Morus bombycis) or peach (Amygdalus persica), possibly because their cell walls are more resistant to the lysis solution. Silver grass (Miscanthus sinensis) and many monocot wild plants could not be lysed by our method, even if the boiling treatment was prolonged (data not shown). This may be because the latter plants belong to the family Poaceae or Cyperaceae, which has a special primary cell wall called a type II wall, which is chemically and structurally different from the cell walls of most dicots as well as some monocots [5, for a review].

\section{Conclusions}

We have developed a chemical method for lysing unground Arabidopsis cells, which is based on cell wall 


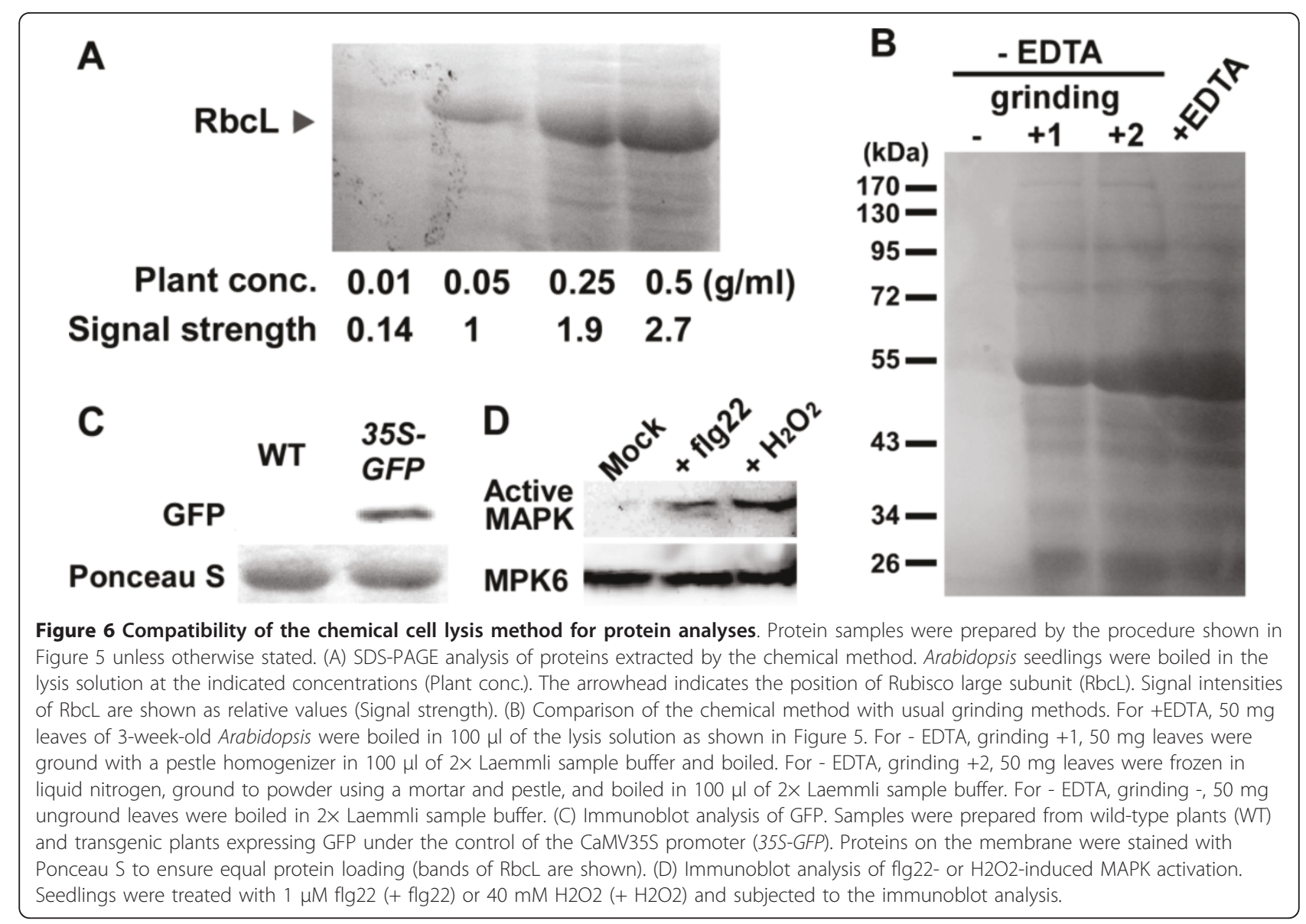

loosening by a $\mathrm{Ca}^{2+}$ chelator and on membrane solubilization by detergent. Our method is applicable to some other species, and cell extracts prepared by our method is suitable for SDS-PAGE, immunoblot and genomic PCR analysis. Our method is rapid, economical, and thus useful for plant research.

\section{Methods}

Chemicals

EDTA (EDTA disodium salt dihydrate) was purchased from Bio-Rad (Japan), EGTA from Sigma (USA), NTA (nitrilotriacetic acid), TTHA (triethylenetetramine- $N$, $N, \quad N^{\prime}, \quad N^{\prime \prime}, \quad N^{\prime \prime}, \quad N^{\prime \prime}$-hexaacetic acid), DTPA

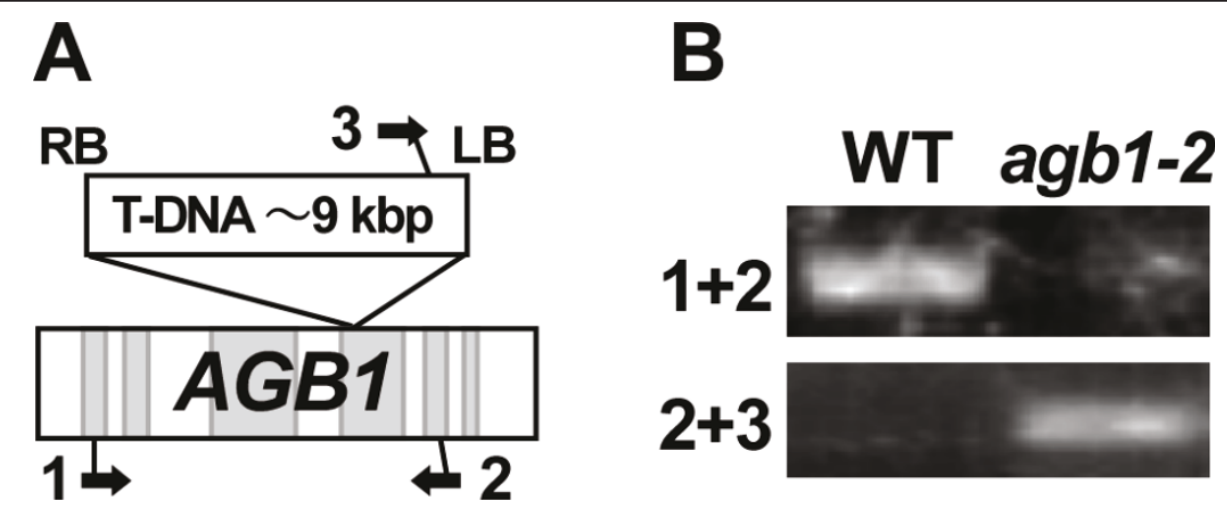

Figure 7 Compatibility of the chemical method for genomic DNA analysis. (A) Diagram of T-DNA insertion in AGB1. Exons are shown as light gray boxes. Arrows 1, 2 and 3 represent AGB1 forward primer, $A G B 1$ reverse primer and T-DNA left border primer, respectively. RB: right border; LB: left border. (B) PCR templates were prepared by the procedure shown in Figure5 from wild-type (WT) and agb1-2 mutant plants. Primer pairs used for PCR are shown as $1+2$ and $2+3$ (the numbers correspond to those in panel A). 


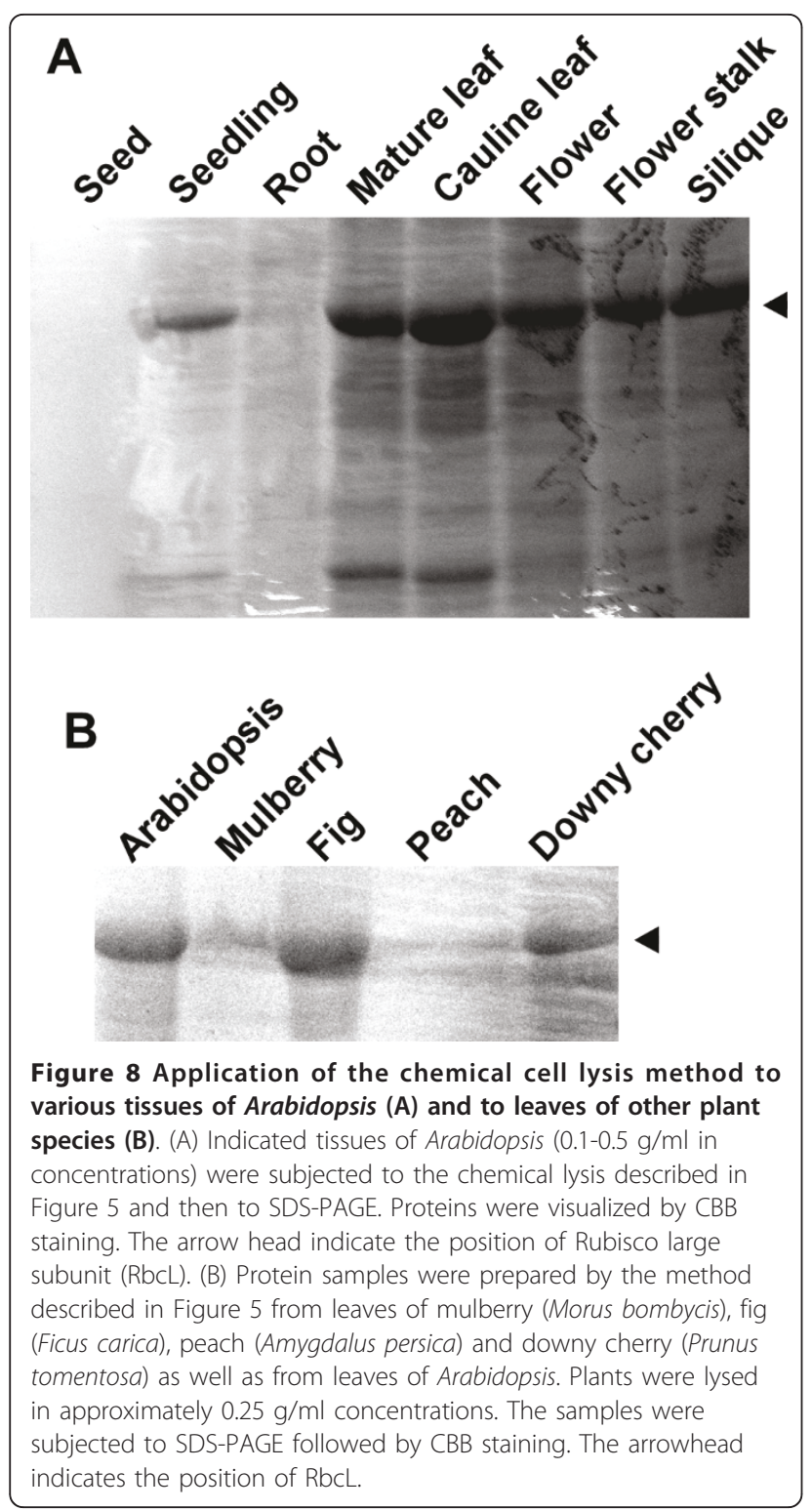

(diethylenetriamine- $N, N, N^{\prime}, N^{\prime \prime}, N^{\prime \prime}$-pentaacetic acid), CyDTA (trans-1,2-diaminocyclohexane- $N, N, N$, $N^{\prime}$ tetraacetic acid, monohydrate) and BAPTA $\left(O, O^{\prime}\right.$-bis (2-aminophenyl)ethyleneglycol- $N, N, N^{\prime}, N^{\prime}$-tetraacetic acid, tetrapotassium salt, hydrate) from Dojindo (Japan). All these chelating agents except EDTA were prepared as $100 \mathrm{mM}$ stock solutions by diluting them in $0.4 \mathrm{M} \mathrm{NaOH}$. EDTA was prepared as a $0.5 \mathrm{M}$ stock solution of $\mathrm{pH}$ 8.0.

SDS, SDSa and Tween 20 were purchased from Wako (Japan), CHAPS from Dojindo, and Brij 35 from Calbiochem. SDS, SDSa and CHAPS were prepared as $10 \% \mathrm{w} / \mathrm{v}$ stock solutions in distilled water, Tween 20 and BriJ 35 as $10 \% \mathrm{v} / \mathrm{v}$. SDS was used in the concentrations described in the figures. SDSa and CHAPS were used in the final concentrations of $0.1-1 \% \mathrm{w} / \mathrm{v}$. Tween 20 and Brij 35 were used in the final concentration of $0.1-1 \% \mathrm{v} / \mathrm{v}$.

\section{Plant materials, growth conditions and plant transformation}

Arabidopsis thaliana ecotype Columbia-0 (Col-0) was used throughout the experiments. Seeds of agb1-2 were obtained from the Arabidopsis Biological Resource Center (ABRC, http://www.arabidopsis.org). Surface-sterilized seeds were sown on the $0.5 \times$ MS medium $(0.8 \% \mathrm{w} / \mathrm{v}$ agar, $0.5 \times$ MS salts, $1 \%$ w/v sucrose, $0.5 \mathrm{~g} / \mathrm{l} \mathrm{MES,} \mathrm{pH} 5.8$ ) for immunoblot and genomic PCR analyses, or in rockwool cubes for the other experiments. In either case, plants were grown at $22^{\circ} \mathrm{C}$ under a 12 -h light/12-h dark photoperiod. To generate transgenic plants expressing GFP, the GUS coding sequence in pBI121 was replaced with the GFP coding sequence, and this construct was used for Arabidopsis transformation by the Agrobacteriummediated floral-dip method [14]. GFP expression in T2 plants was checked by fluorescence microscopy, and GFPpositive plants were used for the immunoblot analysis. Plants other than Arabidopsis were grown in the field and healthy-looking leaves were sampled.

\section{Preparation of Arabidopsis cell extracts}

All the compositions of the solutions and the detailed procedures for the cell lysis experiments are described in each figure. All the lysis solutions were made by mixing stock solutions of their components. For example, the lysis solution for SDS-PAGE in Figure $5(0.1 \mathrm{M}$ EDTA, $0.12 \mathrm{M}$ Tris- $\mathrm{HCl}, 4 \% \mathrm{w} / \mathrm{v}$ SDS, $10 \% \mathrm{v} / \mathrm{v} \beta-\mathrm{ME}$, $5 \% \mathrm{v} / \mathrm{v}$ glycerol and $0.005 \% \mathrm{w} / \mathrm{v}$ bromophenol blue) was prepared by mixing $0.5 \mathrm{M}$ EDTA, $\mathrm{pH}$ 8.0, $1 \mathrm{M}$ Tris$\mathrm{HCl}, \mathrm{pH} 6.8,10 \% \mathrm{w} / \mathrm{v}$ SDS, 100\% $\beta$-ME, 100\% glycerol and bromophenol blue powder to give the final concentrations. Images were processed with Canvas X software (ACD Systems).

\section{SDS-PAGE, immunoblot analysis and genomic PCR analysis}

SDS-PAGE and immunoblot analysis were carried out according to standard procedures $[6,15]$. After CBB staining, signals strengths were quantified using ImageJ software http://rsb.info.nih.gov/ij/index.html. For GFP detection, 7-day-old seedlings grown on the $0.5 \times \mathrm{MS}$ medium were used. For detection of MAPK activation, 14-day-old seedlings were incubated at room temperature for $20 \mathrm{~min}$ in $20 \mathrm{mM}$ Tris- $\mathrm{HCl}, \mathrm{pH} 6.8$ with or without $1 \mu \mathrm{M}$ flg22 or $40 \mathrm{mM} \mathrm{H}_{2} \mathrm{O}_{2}$. Immunoblot analysis was performed using an anti-GFP (MBL, Japan), anti-MPK6 (Sigma) or anti-phospho-p44/42 MAPK (Erk1/2) (Cell Signaling Technology, USA) as a primary antibody, and a horseradish peroxidase-conjugated antirabbit IgG (MBL) as the secondary antibody. Signals 
were detected using SuperSignal West Pico Chemiluminescent Substrate (Thermo Fisher Scientific, USA) and LAS-1000 plus image analyzer (Fuji Film, Japan). After detecting GFP, total proteins on the membrane were stained with Ponceau S solution $(0.2 \% \mathrm{w} / \mathrm{v}$ Ponceau $\mathrm{S}$ in $5 \%$ acetic acid).

For genomic PCR analysis, genomic DNA was prepared from 7-day-old seedlings by the procedure described in Figure 5. PCR was performed using KOD FX (Toyobo, Japan). For $50 \mu \mathrm{l}$ PCR mixture, 1-3 $\mu \mathrm{l}$ of the template solution was added. Primer sequences were as follows: AGB1 forward, 5'-AGACGCCTCCAGCTCCTCGA-3'; AGB1 reverse, 5'-GCACTTCCATCTGCTGACAACCCC-3'; TDNA left border, 5'-CAGGATTTTCGCCTGCTGGGGC$3^{\prime}$. PCR cycle: $98^{\circ} \mathrm{C} 2 \mathrm{~min}, 40$ cycles of $\left(98^{\circ} \mathrm{C} 10 \mathrm{sec}, 60^{\circ} \mathrm{C}\right.$ $\left.30 \mathrm{sec}, 72^{\circ} \mathrm{C} 1 \mathrm{~min}\right), 72^{\circ} \mathrm{C} 7 \mathrm{~min}, 4^{\circ} \mathrm{C}$ until analysis. Images were processed with Canvas X software (ACD Systems).

\section{Abbreviations}

SDS: sodium dodecyl sulfate; PAGE: polyacrylamide-gel electrophoresis; EDTA: ethylenediaminetetraacetic acid; -ME: $\beta$-mercaptoethanol; CBB: Coomassie brilliant blue; EGTA: ethyleneglycol-bis( $\beta$-aminoethyl)tetraacetatic acid; SDSa: sodium N-dodecanoylsarcosinate; CHAPS: 3-[(3-cholamidopropyl) dimethylammonio]propane- sulfonate; GFP: green fluorescent protein; MAPK: mitogen-activated protein kinase; NTA: nitrilotriacetic acid; TTHA: triethylenetetramine- $N, N, N^{\prime}, N^{\prime \prime}, N^{\prime \prime \prime}, N^{\prime \prime \prime}$-hexaacetic acid; DTPA: diethylenetriamine- $N, N, N^{\prime}, N^{\prime \prime}, N^{\prime \prime}$-pentaacetic acid; CyDTA (trans-1,2diaminocyclohexane- $N, N, N^{\prime}, N^{\prime}$-tetraacetic acid; BAPTA: O, O'-bis(2aminophenyl)ethyleneglycol- $N, N, N^{\prime}, N^{\prime}$-tetraacetic acid; MS: Murashige and Skoog; MES: 2-(4-Morpholino)ethane sulfonic acid.

\section{Acknowledgements}

This work was supported by a Grant-in-aid for Scientific Research (21380002) to T.T. and (22-2144) to D.T. We appreciate the kind help of Dr. Daisuke Takata in sampling the field-grown plants. We are grateful to ABRC for providing the Arabidopsis mutant seeds.

\section{Author details}

${ }^{1}$ Asian Natural Environmental Science Center (ANESC), The University of Tokyo, 1-1-1 Midori-cho, Nishitokyo-shi, Tokyo, 188-0002, Japan. ${ }^{2}$ Alkali Soil Natural Environmental Science Center (ASNESC), Northeast Forestry University, Harbin 150040, PR China.

\section{Authors' contributions}

DT designed the experiments. DT and SL performed the experiments. DT and $\Pi T$ wrote the manuscript. All authors read and approved the final manuscript.

\section{Competing interests}

The authors declare that they have no competing interests.

Received: 17 June 2011 Accepted: 15 July 2011 Published: 15 July 2011

\section{References}

1. Kushnirov W: Rapid and reliable protein extraction from yeast. Yeast 2000, 16:857-860.

2. Matsuo Y, Asakawa K, Toda T, Katayama S: A Rapid Method for Protein Extraction from Fission Yeast. Biosci Biotechnol Biochem 2006, 70:1992-1994.

3. von der Haar T: Optimized Protein Extraction for Quantitative Proteomics of Yeasts. PLoS One 2007, 2:e1078.

4. Osumi M: The Ultrastructure of Yeast: Cell Wall Structure and Formation. Micron 1998, 29:207-233.
5. Carpita NC, Gibeaut DM: Structural models of primary cell walls in flowering plants: consistency of molecular structure with the physical properties of the walls during growth. Plant J 1993, 3:1-30.

6. Laemmli UK: Cleavage of structural proteins during the assembly of the head of bacteriophage T4. Nature 1970, 227:680-685.

7. Klimyuk V, Carroll B, Thomas C, Jones J: Alkali treatment for rapid preparation of plant material for reliable PCR analysis. Plant J 1993, 3:493-494.

8. Wang $\mathrm{H}$, Qi M, Cutler A: A simple method of preparing plant samples for PCR. Nucleic Acids Res 1993, 21:4153-4154.

9. Thomson D, Henry R: Single-step protocol for preparation of plant tissue for analysis by PCR. BioTechniques 1995, 19:394-400.

10. Tsien RY: New Calcium Indicators and Buffers with High Selectivity against Magnesium and Protons: Design, Synthesis, and Properties of Prototype Structures. Biochemistry 1980, 19:2396-2404.

11. Asai T, Tena G, Plotnikova J, Willmann MR, Chiu WL, Gomez-Gomez L, Ausubel FM, Sheen J: MAP kinase signaling cascade in Arabidopsis innate immunity. Nature 2002, 415:977-983.

12. Wang $P, D u Y$, Li Y, Ren D, Song C-P: Hydrogen Peroxide-Mediated Activation of MAP Kinase 6 Modulates Nitric Oxide Biosynthesis and Signal Transduction in Arabidopsis. Plant Cell 2010, 22:2981-2998.

13. Ullah H, Chen J-G, Temple B, Boyes DC, Alonso JM, Davis KR, Ecker JR, Jones AM: The $\beta$-subunit of the Arabidopsis $G$ protein negatively regulates auxin-induced cell division and affects multiple developmental processes. Plant Cell 2003, 15:393-409.

14. Clough SJ, Bent AF: Floral dip: a simplified method for Agrobacteriummediated transformation of Arabidopsis thaliana. Plant J 1998, 16:735-743.

15. Towbin H, Staehelin T, Gordon J: Electrophoretic transfer of proteins from polyacrylamide gels to nitrocellulose sheets: procedure and some applications. Proc Natl Acad Sci USA 1979, 76:4350-4354.

doi:10.1186/1746-4811-7-22

Cite this article as: Tsugama et al:: A rapid chemical method for lysing Arabidopsis cells for protein analysis. Plant Methods 2011 7:22.

\section{Submit your next manuscript to BioMed Central and take full advantage of:}

- Convenient online submission

- Thorough peer review

- No space constraints or color figure charges

- Immediate publication on acceptance

- Inclusion in PubMed, CAS, Scopus and Google Scholar

- Research which is freely available for redistribution 